Kunowski, S. (1958). O potrzebie naukowego wyodrębnienia współczesnej pedagogiki katolickiej. Katecheta 4, 285-296.

Kunowski, S. (1959). Teologia a potrzeby pedagogiki katolickiej. Ateneum Kapłańskie, 51(1-3), 233-245.

Pieter, J. (1975). Zarys metodologii pracy naukowej. Warszawa: Państwowe Wydawnictwo Naukowe.

Sztobryn, S. (2010). Historiografia edukacyjna i jej metodologia. Wybrane zagadnienia. W: S. Palka (red.), Podstawy metodologii badań w pedagogice (s. 295-307). Gdańsk: Gdańskie Wydawnictwo Pedagogiczne.

Walulik, A. (2020). Z recenzji wydawniczych. Pobrano 6 listopada 2020 z: http:// www.ssb24.pl/warto_przeczytac,311.

Woroniecki, J. (1961). Program pedagogiki integralnej. W: tenże, Wychowanie człowieka. Pisma wybrane (s. 11-29). Kraków: Wydawnictwo Znak.

\title{
Agnieszka Paczkowska. Dziecko i nastolatek w żałobie. Rola pedagogów i nauczycieli. Gdańsk: Wydawnictwo Fundacji Hospicyjnej, 2019, ss. 128.
}

DOI: http://dx.doi.org/10.12775/PCh.2020.030

Z zaciekawieniem przejrzałem, a potem uważnie przeczytałem praktyczne, a jednocześnie oparte na solidnej wiedzy i doświadczeniu klinicznym, wskazania recenzowanej monografii autorskiej Agnieszki Paczkowskiej, od wielu lat pracującej jako psycholog w gdańskim Hospicjum im. ks. E. Dutkiewicza SAC. Dobrze, że lata praktyki z pacjentami i osieroconymi dziećmi i młodzieżą udało się tak ciekawie przełożyć na dzieło, będące kolejną publikacją z serii Biblioteki Tumbo Pomaga wydawanej przez Fundację Hospicyjną (www.fundacjahospicyjna.pl). Składają się na nie: wprowadzenie, cztery rozdziały, zakończenie i dodatki oraz bibliografia. Każdą z części zamyka praktyczna ramka podsumowująca w skrócie omawianą tematykę. Dzięki temu całość jest przejrzysta i czytelna. Spełnia funkcję poradnika dla praktyków - pedagogów i psychologów szkolnych, nauczycieli i wychowawców, do których głównie jest adresowana, ale stanowi także źródło solidnej wiedzy naukowej, co potwierdza rozbudowany aparat krytyczny z przypisami, do których mogą sięgnąć szczególnie studenci, nauczyciele akademiccy i badacze przedstawianych zagadnień. 
Książkę rozpoczyna wprowadzenie, przybliżające zagadnienie żałoby jako naturalnego, rozciągniętego w czasie stanu, powstającego po śmierci bliskiej osoby, związanego z odczuwaniem smutku, żalu, rozpaczy, złości, poczucia krzywdy i wielu innych emocji. Autorka słusznie zauważa, że proces żałoby dziecka przebiega w sposób bardziej skomplikowany niż u osoby dorosłej, co podkreślają jej wcześniejsze publikacje (Paczkowska i Krakowiak, 2011), a sytuacja dziecka czy nastolatka przeżywającego stratę jest ciągle niedostatecznie rozumiana (de Kergorlay-Soubrier, 2011). Żałoba to długi proces, który może mieć znaczący wpływ na funkcjonowanie dziecka w placówce oświatowej. Dobrze przedstawiono rolę placówki edukacyjnej jako społeczności, która może stanowić ważne wsparcie osieroconego dziecka lub nastolatka. W każdej szkole prędzej czy później pojawi się problem śmierci i żałoby, warto więc znaleźć miejsce i czas na realizację programu prewencyjnego na tematy straty i żałoby oraz podstaw interwencji kryzysowej, niezbędnych w szkołach (Krakowiak, 2008; Binnebesel i in., 2009). Autorka wyjaśnia, iż książka jest zapisem praktycznych doświadczeń Fundacji Hospicyjnej prowadzącej Hospicjum im. ks. E. Dutkiewicza SAC w Gdańsku i programu FDO Tumbo Pomaga, w ramach którego zostały wypracowane materiały dostępne online. Jest wśród nich polecany w książce zestaw narzędzi do działań prewencyjnych oraz interwencji kryzysowej, przygotowany dla pedagogów i dla rodzin. Szczególnie ważne jest przedstawienie form wsparcia edukacyjnego dla nauczycieli i pedagogów (https://tumbopomaga.pl/dla-nauczycieli). Końcowa „ramka podsumowująca” prezentuje w skrócie narzędzia niezbędne do właściwego przygotowania nauczycieli do wsparcia ucznia w żałobie. Zostały tam przedstawione: podręczniki poruszające tematykę śmierci i żałoby i książki dla dzieci poświęcone stracie, w tym terapeutyczne Bajki Plasterki (https://tumbopomaga.pl/biblioteka), wydawane przez Fundację Hospicyjną. Ciekawe są kursy przygotowawcze dla nauczycieli oraz zasoby online niezbędne do pracy z uczniem osieroconym. Służą one wypracowaniu wspólnej dla całej szkoły strategii wobec osieroconych uczniów, wskazując na potrzebę dostępu do pomocy psychologicznej. Nauczyciel słusznie został ukazany jako refleksyjny praktyk, a autorka dobrze wykorzystuje do zilustrowania refleksyjności pięć kluczowych kompetencji według Zeichnera i Liston: doświadczenie oraz uczenie się poprzez rozwiązywanie problemów/ /dylematów; świadomość osobistych założeń i wartości przenoszonych na grunt uczenia się; zwracanie uwagi na kontekst danej sytuacji, w której przebiega uczenie się; wprowadzanie zmian oraz branie udziału w opracowaniu programów nauczania/treści kształcenia; przejmowanie odpowiedzialności za swoje uczenie się i rozwój zawodowy (Zeichner i Liston, 1996). Obszar 
refleksyjnej praktyki dobrze pasuje do edukacji i wsparcia osieroconych uczniów i właśnie tą metodą odbywała się opisana w tym dziele edukacja nauczycieli w programie FDO Tumbo Pomaga. Gdańsk jest obecnie jedynym miejscem w Polsce, w którym ponad 100 placówek oświatowych zostało przygotowanych teoretycznie i praktycznie do pomocy osieroconemu uczniowi oraz do właściwego reagowania na kryzys związany z żałobą dotykającą szkolną społeczność (Paczkowska et al., 2018). Na koniec wstępu w skrócie przedstawiono cele edukacyjne programu psychoedukacyjnego FDO Tumbo Pomaga: wprowadzenie w zagadnienia związane ze śmiercią i żałobą; przedstawienie podstawowych, codziennych sposobów wsparcia ucznia i nauczyciela w żałobie; wypracowanie strategii postępowania szkoły w sytuacji kryzysowej, jaką jest śmierć w społeczności szkolnej; uwypuklenie różnic w postępowaniu w sytuacji żałoby w wyniku śmierci nagłej (wypadek, samobójstwo) oraz śmierci w rodzinie ucznia i śmierci dotyczącej całej społeczności szkolnej. Jest to kontynuacja projektów rozpoczętych przez Fundację Hospicyjną ogólnopolską kampanią społeczną dotyczącą żałoby (Krakowiak, 2012), przeniesioną do środowisk szkolnych. Wprowadzenie przygotowuje czytelnika do wykorzystania zasobów tej publikacji i towarzyszących jej licznych materiałów multimedialnych, dostępnych online.

Pierwszy rozdział nosi tytuł „FDO Tumbo Pomaga”, gdzie FDO to Fundusz Dzieci Osieroconych. Rozpoczyna go uwaga, że często dorośli z otoczenia osieroconego dziecka, sami pogrążeni w żalu, nie dostrzegają żałoby dzieci, co czyni je „zapomnianymi żałobnikami”. Sytuacja dziecka czy nastolatka po stracie bywa niedostatecznie rozumiana, co potwierdzają statystyki i przedstawione liczby, oparte na badaniach skomplikowanej żałoby (Kaplow i in., 2012). Konsekwencją braku wsparcia bywa patologizacja żałoby i rozwój problemów edukacyjnych. Zmniejszenie odsetka dzieci potrzebujących pomocy w wyniku powikłania procesu żałoby jest zatem kluczową misją pedagogów. Detalicznie przedstawiona edukacja nauczycieli w programie FDO Tumbo Pomaga zawiera zasoby portalu edukacyjnego dla osieroconych dzieci i ich opiekunów oraz nauczycieli, a także telefon zaufania dla osób w żałobie. Wyjaśniono założenia wydarzeń edukacyjno-charytatywnych w placówkach oświatowych o nazwie Dzień Tumbo, prezentując ich przebieg i propozycje zajęć edukacyjnych. Dalsza część poświęcona jest ważnym dla pedagogów etapom nauczania refleksyjnego, opisywanego w naukach społecznych (Gołębniak, 1998). Chodzi o zorientowanie na rozwiązanie problemu, umiejętność pracy w grupie, ale także samodzielną naukę, która będzie też wypełnioną refleksją praktyką dotyczącą sytuacji kryzysu choroby i straty. Rozdział kończy ramka podsumowująca, przedstawia- 
jąca w skrócie cele edukacyjne programu psychoedukacyjnego FDO Tumbo Pomaga. Wprowadzenie w zagadnienia związane ze śmiercią i żałobą, a także przedstawienie podstawowych, codziennych sposobów wsparcia ucznia i nauczyciela w żałobie są prosto wyjaśnione. Cenne jest ukazanie strategii postępowania szkoły w sytuacji kryzysowej, jaką jest śmierć w społeczności szkolnej, oraz uwypuklenie różnic w postępowaniu w sytuacji żałoby w wyniku śmierci nagłej (wypadek, samobójstwo) oraz śmierci w rodzinie ucznia i śmierci dotyczącej całej społeczności szkolnej.

Kolejny rozdział omawia „Wsparcie emocjonalne osieroconych dzieci i nastolatków". Zrozumienie skomplikowanego procesu żałoby dzieci i młodzieży oparto $\mathrm{w}$ tej pracy na doświadczeniach irlandzkiej organizacji Irish Childhood Bereavement Network (Childhood Bereavement, online). Przez ilustrację piramidy określa ona powszechność/częstotliwość występowania potrzeb dotyczących: większości dzieci i młodzieży (Poziom 1); niektórych dzieci (Poziom 2 i Poziom 3); nielicznych dzieci (Poziom 4), a więcej na temat piramidy potrzeb nazwanej: The Irish Childhood Bereavement Care Pyramid znaleźć można online, podobnie jak świadectwa nauczycieli różnych poziomów (https://www.childhoodbereavement.ie/schools/primary-school-teachers/).

Rodzina i lokalna społeczność odgrywają zasadniczą rolę we wsparciu dzieci i młodzieży w okresie żałoby, a szkoła może być pomocna na różnych poziomach, dostosowując sposób wsparcia uczniów w żałobie do sytuacji w rodzinie i w jej otoczeniu. Kończąca tę część pracy ramka przypomina ważne prawdy dla praktyków edukacji, które warto tu powtórzyć: niektóre dzieci od razu wchodzą w okres żałoby, prezentując zmienne nastroje i zachowania, ale wiele dzieci potrzebuje czasu, by powoli odzyskać poczucie bezpieczeństwa i zacząć przetwarzać to, co się wydarzyło; dorastając, dzieci ponownie wracają do tematu śmierci, a pytania, które zadają na temat śmierci, obrazują wewnętrzny świat ich przeżyć; istnieją czynniki ryzyka powikłania procesu żałoby, których wystąpienie wymaga porad specjalisty. Cenne wydają się także dyrektywne wskazania dla praktyków edukacji w stylu: „okaż szacunek i bądź uczciwy", bo prawdziwie istnieją pytania, na które nie ma wyczerpującej odpowiedzi, co potwierdzają publikacje zajmujące się komunikacją u kresu życia (Janowicz i in., 2014).

W trzeciej części recenzowanej książki opisana została „Interwencja kryzysowa w placówce edukacyjnej”. W zależności od sytuacji i rodzaju śmierci interwencja kryzysowa będzie różniła się zakresem, co autorka w swoim projekcie i w tym dziele cytuje i przywołuje jeden z modeli interwencyjnych z programu A strategy for schools brytyjskiej organizacji Winston's Wish 
(https://www.winstonswish.org/). Rzetelnie przedstawia różne formy interwencji, a szczególnie często pomijane po pierwszych etapach kryzysowej interwencji wsparcie długoterminowe. Obejmuje ono: zaplanowanie działań o charakterze symbolicznym, upamiętniających osobę zmarłą, takich jak rocznice śmierci czy urodzin zmarłego; przygotowanie ogólnodostępnych informacji, wskazujących, gdzie można szukać pomocy psychologicznej w aspekcie przeżywanej żałoby; rozpowszechnienie krótkiej informacji na temat podstawowych aspektów przeżywania żałoby; zorganizowanie szkoleń dla pracowników szkoły dotyczących procesu żałoby odbywających się w późniejszym terminie, np. po dwóch miesiącach; zorganizowanie spotkań dla uczniów dotyczących tematu śmierci i żałoby w późniejszym terminie. W zakończeniu tego ważnego dla praktyków interwencji kryzysowych w szkołach rozdziału opisano ryzyka stresu związanego ze śmiercią ucznia lub pracownika szkoły, na które narażeni są nauczyciele i uczniowie znający zmarłego, a także przyjaciele osoby zmarłej. Cierpią też osoby, które znajdują analogię swojej sytuacji z tą, w jakiej znajdował się zmarły, a śmierć w wyniku samobójstwa (na skutek depresji) może wzbudzić większy lęk wśród osób chorujących na depresję. Zauważono osoby w procesie żałoby lub z wcześniejszymi doświadczeniami strat, osoby mające nieodpowiednie relacje ze zmarłym i osoby z problemami emocjonalnymi. Dobrze opisano zagadnienie pamięci o zmarłym, a cenne jest stwierdzenie, iż sposoby upamiętnienia zmarłego proponowane przez nauczycieli powinny być przy tym zgodne z aktualnymi potrzebami danej klasy czy uczniów (Grzybowski, 2009). Książka porusza też temat uroczystości pogrzebowych oraz przedstawia dalsze działania, do których należą między innymi: pisanie listów, tworzenie rysunków dla członków rodziny osoby zmarłej czy zasadzenie drzewka symbolizującego pamięć o zmarłym. Dobrze, że wskazano również na potrzebę stworzenia miejsca pamięci na terenie szkoły oraz podano informacje o tym, co zrobić z przedmiotami zmarłego. Także kontakty z rodziną zmarłego od kondolencji po dalsze kontakty zostały dobrze przedstawione, z zaleceniami działania z wyczuciem i zwróceniem uwagi na rodziny, które mogą dążyć do odcięcia swoich związków ze szkołą i otoczeniem.

Ostatni rozdział publikacji nosi tytuł: „Edukacja na temat śmierci”, co jest ważne w tym poradniku dla nauczycieli, mogących towarzyszyć uczniom zmagającym się z ciężką chorobą i umieraniem, a przede wszystkim z żałobą. Dobrze przypomniano czynniki mogące blokować rozpoczęcie żałoby lub utrudnić jej domknięcie. Słusznie wskazano działania profilaktyczne jako sposób na zmniejszenie odsetka dzieci doświadczających powikłań w przebiegu żałoby. Prezentację rozwiązań systemowych rozpoczyna kompleksowy 
projekt zaproponowany przez zespół Fundacji Hospicyjnej - FDO Tumbo Pomaga. Rozpoczęty od prewencji i wczesnej interwencji wobec osieroconych, poprzez część socjalną, psychosocjalną i psychopedagogiczną program ma pomagać: przełamywać tabu śmierci i towarzyszące im stereotypy; upowszechniać wiedzę na temat potrzeb osób w żałobie; zwiększać umiejętności nauczycieli i specjalistów w zakresie psychoedukacji, doradztwa i oddziaływań terapeutycznych wobec rodzin i uczniów. Opisano inicjatywę szkoleń dla ponad 100 placówek z Gdańska i Pomorza i przypomniano publikację Jak rozmawiać z uczniami o końcu życia i wolontariacie hospicyjnym, zawierającą narzędzia dydaktyczne dla nauczycieli i wychowawców (Binnebesel i in., 2009).

Zakończenie jest podsumowaniem zrealizowanego projektu edukacyjnego, którego przebieg i efekty opisuje recenzowana książka. Znalazło się tu także miejsce na badania Fundacji Hospicyjnej z lat 2015-2016, obejmujące ponad 300 ankiet ewaluacyjnych przeprowadzonych po zakończeniu szkoleń dla nauczycieli. To podnosi wartość poznawczą i naukową tego dzieła, które łączy nową wiedzę oraz prezentowane już częściowo wcześniej (Paczkowska i in., 2018) doświadczenie praktyczne w zakresie wsparcia dzieci i dorosłych $\mathrm{w}$ żałobie. Zgadzam się z zaproponowaną przez autorkę w zakończeniu koniecznością popularyzacji wiedzy o potrzebach osieroconych dzieci i nastolatków poprzez: wydarzenia edukacyjno-społeczne dla lokalnych społeczności; wczesną edukację dzieci w zakresie zjawisk ciężkich chorób, śmierci i żałoby; dostęp do konsultacji psychologicznych bezpośrednich, telefonicznych i online dla dzieci, młodzieży i dorosłych; dostęp do narzędzi psychoedukacyjnych w postaci publikacji książkowych i publikacji online; szkolenia dla dorosłych mających kontakt z dziećmi i młodzieżą. Niniejsza publikacja spełnia część z zawartych na koniec tego rozdziału postulatów.

Dobrze, że w recenzowanej książce działania podejmowane przez Fundację Hospicyjną w programie Fundusz Dzieci Osieroconych Tumbo Pomaga praktycznie i przystępnie ukazały pierwsze w Polsce systemowe wsparcie dzieci i młodzieży po stratach poprzez edukację nauczycieli. Choć ważne jest w przygotowaniu nauczycieli, by uczyć się myśleć jak pedagog (Śliwerski, 2010), to słusznie wskazano, jak refleksyjność pedagogów wpływa na lepsze radzenie sobie z kryzysami po stratach $\mathrm{u}$ ich uczniów. Wypracowany model współpracy ze szkołami, zaprezentowane w książce narzędzia edukacyjne oraz ten przewodnik - podręcznik poświęcony wsparciu w żałobie przez nauczycieli stanowią dobry punkt wyjścia do rozwijania gdańskiego modelu opieki nad osieroconymi uczniami w całym kraju. Skoro w Gdańsku 
w latach 2014-2019 udały się systemowe działania z udziałem władz miasta i nauczycieli, a materiały edukacyjne przyniosły korzyści lokalnej społeczności, z pewnością warto je szerzej propagować. Niewątpliwie pedagodzy powinni sięgnąć po tę publikację. Warto w praktyce edukacyjnej przenieść doświadczenia regionalne na całą Polskę we współpracy z hospicjami, szkołami i lokalnymi społecznościami. Ważna jest dalsza edukacja społeczna na temat śmierci i żałoby w szkołach, a także kolejne publikacje popularnonaukowe i badania nad skutecznością realizowanego tam wsparcia. To ważna i potrzebna lektura dla nauczycieli i studentów pedagogiki i nauk społecznych, ale także dla wszystkich, którzy nie chcą pozostawić cierpiących w samotności po stratach dzieci i młodzieży. Cennymi i ciągle za mało znanymi wśród pedagogów pomocami są przedstawione tutaj materiały online Funduszu Dzieci Osieroconych - Tumbo Pomaga oraz książki z Biblioteki Fundacji Hospicyjnej (https://ksiegarnia.hospicja.pl/).

Piotr Krakowiak*

ORCID: 0000-0002-0500-4954

Toruń, Polska

\section{Bibliografia}

Binnebesel, J., Janowicz A. i Krakowiak P. (red.) (2009). Jak rozmawiać z uczniami o końcu życia i wolontariacie hospicyjnym. Gdańsk: Fundacja Hospicyjna.

Gołębniak, B. D. (1998). Zmiany edukacji nauczycieli. Wiedza - Biegłość - Refleksyjność. Toruń-Poznań: Edytor.

Grzybowski, P. (2009). Praktyczne cele i aspekty kształcenia tanatologicznego pedagogów i nauczycieli. W: Binnebesel J., Janowicz A. i Krakowiak P. (red.), Jak rozmawiać z uczniami o końcu życia $i$ wolontariacie hospicyjnym (s. 7-19). Gdańsk: Fundacja Hospicyjna.

Janowicz, A., Krakowiak, P., Paczkowska, A. i Sikora, B. (2014). Zdrowa rozmowa. Sztuka komunikacji z osobami u kresu życia. Gdańsk: Fundacja Hospicyjna.

Kaplow, J., Layne, C., Pynoos, R., Cohen, J. i Lieberman A. (2012). DSM V diagnostic criteria for bereavement-related disorders in children and adolescents: developmental considerations. Psychiatry, 75(3), 243-266.

* Dr hab. Piotr Krakowiak, prof. UMK, Wydział Filozofii i Nauk Społecznych, Instytut Nauk Pedagogicznych, Uniwersytet Mikołaja Kopernika w Toruniu, e-mail: pkrakow@umk.pl. 
Kergorlay-Soubrier, M.-M. de (2011). Śmierć oczami dziecka jak pomagać w żałobie? Kraków: Wydawnictwo Salwator.

Krakowiak, P. (2008). Strata, osierocenie, żałoba. Poradnik dla pomagajacych i osób w żałobie. Gdańsk: Fundacja Hospicyjna.

Krakowiak, P. (2012). Społeczne i edukacyjne funkcje opieki paliatywno-hospicyjnej. Badanie w działaniu 2002-2010. Gdańsk: Fundacja Hospicyjna.

Paczkowska A., Krakowiak P. i Wojtacki, J. (2018). „Tumbo pomaga” jako forma wsparcia dla osób w okresie żałoby. Jak pracownicy oświaty oceniają kształcenie w zakresie wsparcia dziecka po stracie bliskich? Podsumowanie wybranych działań edukacyjnych Fundacji Hospicyjnej w Gdańsku w latach 2015-2018. W: Materiały konferencyjne XII Konferencji Czasopisma „Palliative Medicine in Practice", 7-8.06.2018, Gdańsk.

Paczkowska, A. i Krakowiak, P. (2011). Śmierć w świecie dziecka - komunikacja z dzieckiem w żałobie. W: Antoszewska B. (red.), Dziecko przewlekle chore-problemy medyczne, psychologiczne i pedagogiczne (s. 164-174). Toruń: Wydawnictwo Edukacyjne Akapit.

Śliwerski, B. (2010). Myśleć jak pedagog. Sopot: GWP.

Zeichner, K. M. i Liston, D. P. (1996). Reflective Teaching: An Introduction. New York: Routledge. 